\begin{tabular}{lccc} 
& GOSPODARKA & SUROWCAMI & MINERALNYMI \\
\hline Tom 29 & 2013 & Zeszyt 2 \\
& & DOI 10.2478/gospo-2013-0012 &
\end{tabular}

\title{
The basic assumptions of the quantitative version of the Comprehensive Method of Rockburst Hazard Evaluation
}

\begin{abstract}
Introduction
In the Polish mining industry, an evaluation called "The Comprehensive Method of Rockburst State-of-Hazard Evaluation" (CMRHE) is commonly applied to assess rockburst hazard. The CMRHE is composed of four "particular" methods, i.e. Mining Seismology, Seismoacoustics, Small-diameter Drilling Method, and Expert Method of Hazard Evaluation - the last of these further abbreviated as MRG (an acronym of the Polish description: "Metoda Rozeznania Górniczego"). When applied, the particular methods produce their own (hazard) scores and the CMRHE, weighting them appropriately, generates the final score called "the current state of rockburst hazard". This score is then communicated to managers in order to facilitate decisions concerning production and safety. The methods of seismoacoustics, seismology, and drilling are based on measurements, while scores issued by the MRG depend on the sum of points $Q\left(i, \theta_{i}\right)$, where " $i$ " denotes a particular hazard shaping factor or $\operatorname{HSF}(i)$, and $\theta_{i}$ is its local value. For example, if $\operatorname{HFS}(1)$ is the exploitation depth, then according to MRG $Q\left(1, \theta_{1}\right)=0$ if $\theta_{1}<400 \mathrm{~m}, Q\left(1, \theta_{1}\right)=1$ if $400<\theta_{1}<700 \mathrm{~m}$, and $Q\left(1, \theta_{1}\right)=2$ if $\theta_{1}>700 \mathrm{~m}$. This article does not describe the physical basis of CMRHE or the choice of HSFs, accepting them as presented in the CMRHE and the MRG Instruction. Instead, this analysis converts the "expert" scoring into a formal, quantitative model expressing and processing the probabilities of events, which among other things allows for optimization.
\end{abstract}

* Ph.D. Eng., ** Professor, Główny Instytut Górnictwa, Katowice, Poland; e-mail: jkurzeja@gig.eu 
A longer (English) description of CMRHE can be found in the work of Kornowski and Kurzeja (2012) and the full description (in Polish) can be found in the Instruction of the CMRHE (Baranski et al. 2007), from now on called the CMRHE Instruction, where individual chapters are devoted to particular methods (e.g. ch. 2 provides the MRG Instructions).

Unfortunately, the CMRHE Instruction does not quantitatively define the rockburst hazard, nor do it's instructions for particular methods. The variables are not well defined, thus the process retains a level of uncertainty that particular scores are commensurate and allow for logically justified combinations (to generate the final score of the state of hazard). This makes for an uncomfortable situation CMRHE is based on the judgement of experience. While it is commonly applied in the Polish coal-mining industry with some success and thus cannot be disregarded, its logical basis and correctness is unclear. As a result, this work attempts to evaluate, classify, and predict those variables.

The goal this paper is to describe the proposed logical foundations of the method and to demonstrate that this results in a Quantitative Version of the CMRHE (abbreviated IWMK), where all the (partial and final) quantities and scores have a clear probabilistic interpretation and can (and should) be operated exclusively according to probability rules.

The IWMK has been previously described by Kornowski (2010) in Polish and by Kornowski and Kurzeja (2012) in English. Its possible applications can now be further explained.

As this analysis concerns mining-induced seismicity, the term "seismic emission" means "the process of emitting mining-induced seismic events", unless stated otherwise.

\section{Basic notions and definitions}

The definition of generally accepted risk is usually expressed as the product of the event's probability $(P)$ and the economic loss when it happens (e.g. Falanesca et al. 2010; De Groot 1970):

$$
\{\text { risk }\}=\{\text { probality of event }\} \cdot\{\text { economic loss due to its occurrence }\}
$$

(This definition becomes slightly more complicated and includes integration if, instead of probability, one uses its density.)

To avoid inconclusive and unpopular discussions of the costs of human life or disaster, this analysis omits the second factor (i.e. loss) in equation 1.1, and - to avoid terminological confusion - it applies the (known and popular) name hazard $(Z)$. Thus, in this paper:

$$
\{\text { hazard }\}=\{\text { probality of event }\}
$$


This definition is well known and long recognized, for example, in the field of seismology (Gibowicz, Kijko 1994, p. 301), but the notion of probability seems to be unpopular among industrial users, so it should be stressed that equation (1.2) is to be taken seriously. Every formula expressed in terms of probability $P$ (for mathematically inclined readers) can also be expressed in terms of hazard $Z$ (for industrial users) and vice-versa, simply substituting $Z \equiv P$. In this paper, both notations are applied.

According to industrial practice, this analysis differentiates tremor (a local seismic event, registered by the local seismic network) from rockburst (a tremor with disastrous effects). As stressed by Dubinski (1994), there is no rockburst without a tremor but, very fortunately, only a small fraction of tremors cause rockbursts.

It is then possible to define relevant hazards. The three definitions D1, D2, D3 listed below should be interpreted together with Fig. 1, illustrating connections among the hazards (or probabilities):

D1 Seismic hazard, $Z^{S}-$ or $\left(Z^{S}\right)_{\Delta t}^{12}$ or $Z^{S}[(t, t+\Delta t),(E 1, E 2), R]$ with $R$ being the space segment (e.g. longwall), $(E 1, E 2)$ is the energy interval allowing $E 2$ $\rightarrow \infty, \Delta t$ the so called prediction horizon - the probability of a seismic event inside the limits of $[(t, t+\Delta t),(E 1, E 2), R]$.

The upper index " $S$ ", in $Z S$, means "seismic". It should be noted that the "time, space, and energy" of event is chosen beforehand by the user as "the space of his interests". It is assumed that the industrial prediction user is always able to approximately define the limits of his interest. From the definition D1:

$$
Z^{S} \equiv P(E 1 \leq E \leq E 2)
$$

or

$$
Z^{S} \equiv P(E>E 1)
$$

Given the archive of seismic events from the observed region $R$ and assuming a stationary-Poisson emission process (which is observationally confirmed for energies above $1 \cdot 10^{2}$ J, (Kornowski, Kurzeja 2008) and (Lasocki 1990) for "strong mining events"), probability (1.2) can easily be estimated as shown in ch. 4. From the probability definition it is known that:

$$
0 \leq Z^{S} \leq 1
$$

So that "the space of possible hazards" (i.e. interval 0-1) can always be divided into segments (e.g. a, b, c, d) called "states of seismic hazard", to simplify the decision making process. Next, it is possible to define:

D2 Seismic rockburst hazard, $Z^{S T}-$ or $\left(Z^{S T}\right)_{\Delta t}^{12}$ or $Z^{S T}[(t, t+\Delta t),(E 1, E 2)$, $\left.R, \theta_{\mathrm{E}}\right]$ where $\theta_{\mathrm{E}}$ is the parameters vector - the probability of rockburst due 
to a seismic event inside the limits $[(t, t+\Delta t),(E 1, E 2), R]$, given the $\operatorname{parameter(s)} \theta_{E}$.

The name "Seismic rockburst hazard" has been coined to stress that mining and geological "hazard shaping factors" (described in the MRG Instruction, Baranski et al. 2007 ch. 2) are not taken into account. Only the probability of the tremor $(E 1<E<E 2)$ and probability that the tremor of energy $E$ results in rockburst determine $Z^{S T}$. The variable $Z^{S T}$ is not another real hazard. It is only a convenient partial result (see Fig. 1) of the estimation procedure (because $Z^{T}=Z^{S T} \cdot Z^{M R G}$ ).

According to probability rules and as shown in Fig. 1:

$$
Z^{S T}=P(E>E 1) \cdot P(T \mid E>E 1)
$$

Conditional probability is a mathematical phrase. In engineering terminology it is called "rockburst-energy characteristics" analogously to "amplitude-frequency characteristics" (known in oscillation measurements) and can simply be denoted $F\left(\theta_{E}\right)$. With a given $E 1$ value, $P(T \mid E>E 1) \equiv F\left(\theta_{E} \mid E>E 1\right) \equiv F\left(\theta^{*}{ }_{E}\right)$ becomes a scalar, multiplicatively "amplifying" (despite that $0 \leq F\left(\theta_{E}\right) \leq 1$ ) the probability of rockburst.

These characteristics can be approximated using the logistic curve of parameters $\left(\theta_{E}\right)$ estimated from the catalogue of tremors and rockbursts. The procedure of $\theta_{E}$ estimation from data is called the calibration of characteristics and is discussed in ch. 3 . One more definition is needed:

D3 Rockburst hazard, $\boldsymbol{Z}^{\boldsymbol{T}}-$ or $\left(Z^{S T}\right)_{\Delta t}^{12}$ or $Z^{T}[(t, t+\Delta t),(E 1, E 2), R, S C N]$ where $S C N$ is a general scenario, including and all the other locally active "hazard shaping factors", enumerated in the MRG Instruction - the probability of rockburst inside the limits $[(t, t+\Delta t),(E 1, E 2), R]$, given the full, quantitative description of SCN.

It should be repeated that the "time, place, and energy" are specified beforehand and only the value of probability is predicted. This construction of definition makes it operational. Given the data, scalar $Z^{T}$ value can be calculated. Again, the interval (0-1) can be divided into segments (e.q. $0-10^{-5}-10^{-4}-10^{-3}-1$ ) called states of rockburst hazard (e.g. A, B, C, D) which are communicated to users.

According to probability rules, and as shown in Fig. 1:

$$
\begin{gathered}
Z^{T}=Z^{S T} \cdot Z^{M R G} \\
Z^{M R G=} F\left(\theta_{1}\right) \cdot F\left(\theta_{2}\right) \cdot \ldots \cdot F\left(\theta_{M}\right)
\end{gathered}
$$

or, equivalently

$$
P(T)=P(E>E 1) \cdot P(T \mid E>E 1) \cdot P\left(T \mid \theta_{1}\right) \cdot \ldots \cdot P\left(T \mid \theta_{M}\right)
$$




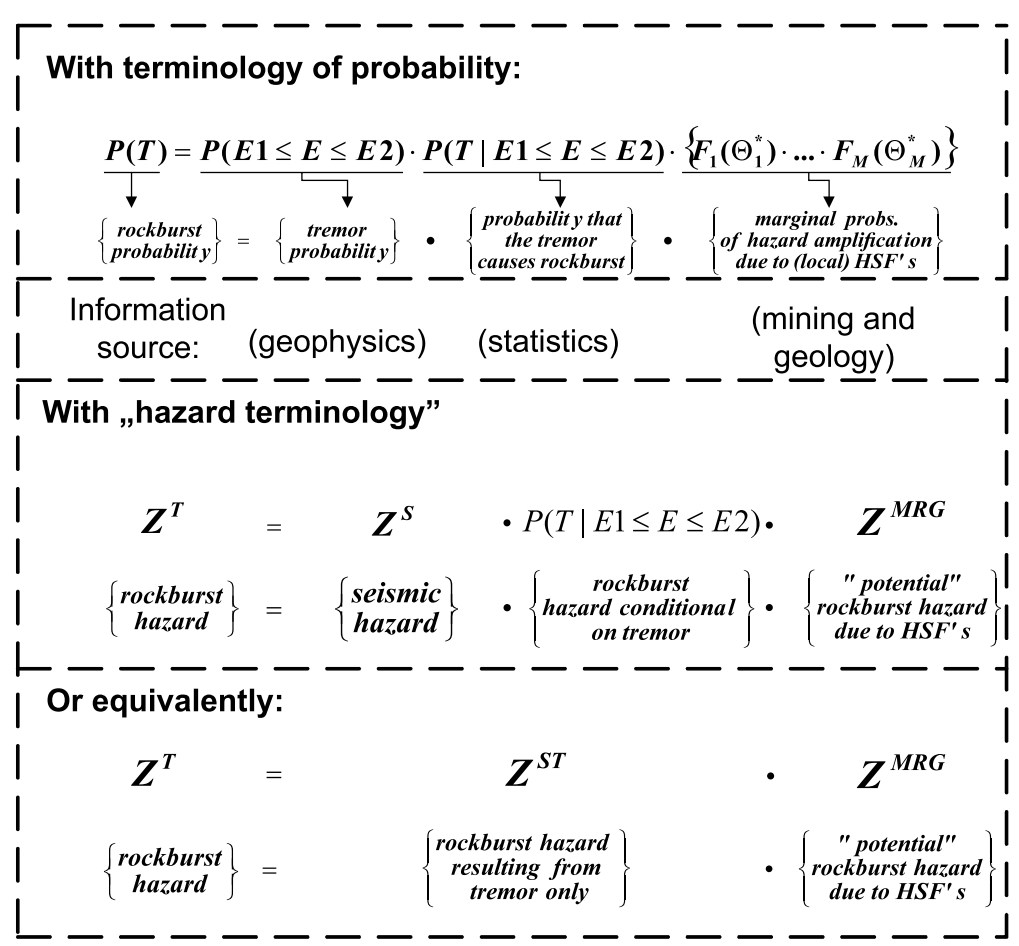

Fig. 1. Basic decomposition forms of rockburst hazard estimator, $Z^{T}$ HSF - hazard shaping factor

Rys. 1. Podstawowe formy dekompozycji estymatora zagrożenia tąpnięciem $Z^{T}$ HSF - czynnik kształtujący zagrożenie

The number of HSF's - or the dimension of "factors' space" - must be constant during the hazard estimation.

\section{Factorial characteristics} or conditional probabilities of rockburst

According to (1.6c), rockburst probability $P(T),-$ also called the rockburst hazard $\left(Z^{T}\right)-$ is the product of $P(E>E 1)$ - or seismic hazard - and a series of factors $P(T \mid E>E 1)$, $P\left(T \mid \theta_{1}\right), \ldots, P\left(T \mid \theta_{M}\right)$ which, except for the first one, are collectively called, "hazard shaping factors" (HSFs) in the MRG Instruction.

Estimating relation $P\left(T \mid \theta_{i}\right)$ between the hazard amplification and the $\operatorname{HSF}(i)$ - with its independent variable $\theta_{i}$ - can generally be seen as a complicated inverse problem (Tarantola 1987; Marcak 2009) where the data are sparse (yearly only a few rockbursts occur in the Polish mining industry) and the results are very sensitive to observational inaccuracies. 
The problem becomes simpler taking into account that the characteristics $P\left(T \mid \theta_{i}\right)$ for any " $i$ " must - by definition - have two asymptotes and that - if HSFs are approximately independent - the probabilities can simply be multiplied and $P\left(T \mid \theta_{i}\right)$ interpreted as "factorial characteristics" with values generalizing the "points" of MRG Instruction. This is the IWMK approach.

HSFs may be interpreted (Kornowski, Kurzeja 2012) both as conditional (and marginal) probabilities of rockburst given $\theta_{i}$ or as characteristics $F\left(\theta_{i}\right)$, expressing amplification of rockburst probability as a function of $\theta_{i}$. For example, in the MRG Instruction, HFS(1) is the local depth $(H,[\mathrm{~m}])$ of exploitation. Then $F\left(\theta_{1}\right)=F(H)$ is a function expressing the dependence of $P(T)$ on the exploitation depth only, provided a tremor has occurred. Any factorial characteristics $F\left(\theta_{i}\right)$, can also be interpreted as probability $F\left(\theta_{i}\right) \equiv P\left(T \mid \theta_{i}\right)$, and as a result, it can be very conveniently approximated with a logistic function, for example:

$$
F(H)=\left\{1+\exp \left[-\alpha_{H}\left(H-\beta_{H}\right)\right]\right\}^{-1}
$$

with parameters $\alpha_{H}, \beta_{H}$ (or $\alpha_{\theta i}, \beta_{\theta i}$ generally) estimated from the local catalogue of tremors and rockbursts at various depth intervals. The process of parameters estimation is called the calibration (of factorial characteristics). Given the local information in the form of the events catalogue, one can find optimally calibrated factorial characteristics and, for a given value of $\theta_{i}{ }^{*}$, an optimal factorial amplification coefficient, $F\left(\theta_{i}{ }^{*}\right)$, which multiplicatively modifies the probability of rockburst. The authors of this paper believe that optimal values of $F\left(\theta_{i}^{*}\right)$ for any $i$-th $\operatorname{HSF}(\mathrm{i})$ and its local value $\theta_{i}-$ can and should be used in the practice of hazard evaluation, instead of the "points" mentioned earlier (with the exception of the case of equation (2.3b) mentioned later). Additionally, it can be noted that the logarithm of $(\mathbf{1 . 6 a}, \mathbf{b})$ - or $(1.6 a, c)$ - results in the sum of scalar values which may be rounded (each one to the nearest integer) and called the "optimal points", stressing the simple connection between the original MK and our IWMK, but such an operation is inadvisable. There is no reason to round the optimal values of amplification coefficients $F\left(\theta_{i}\right)$. They can be used as they are, simply inserted into (1.6b) or (1.6c).

To illustrate the calibration procedure, the short Table 1 below (see Kornowski, Kurzeja 2008) shows tremors, rockbursts, and "observed" probabilities (i.e. proportions) of rockburst in Polish coal mines during the period 1997-2006, for energies above some $E$ values.

The well-known logit transformation changes the fitting problem into a linear one and allows for the approximate but simple fitting of the logistic function to the data. From this we obtain:

$$
P(T \mid E>E 1)=\frac{1}{1+\exp [-1.676(\log E 1-8.438)]}
$$


Tremors, rockbursts and "observed" probabilities $P(T \mid E>E 1)$ of rockburst in Polish coal mines in various energy intervals

Statystyka wstrząsów i tąpań w polskim górnictwie węgla kamiennego dla wstrząsów w kolejnych przedziałach energii

\begin{tabular}{||l|c|c|c|c||}
\hline \multirow{2}{*}{} & \multicolumn{4}{|c||}{ Energy interval [J] } \\
\cline { 2 - 5 } & $E>1 \cdot 10^{5} \mathrm{~J}$ & $E>1 \cdot 10^{6} \mathrm{~J}$ & $E>1 \cdot 10^{7} \mathrm{~J}$ & $E>1 \cdot 10^{8} \mathrm{~J}$ \\
\hline \hline Number of tremors, $N^{W}$ & 10974 & 1719 & 164 & 6 \\
\hline Number of rockbursts, $N^{T}$ & 36 & 27 & 13 & 2 \\
\hline Observed proportion & 0.00328 & 0.01571 & 0.07968 & 0.3333 \\
\hline
\end{tabular}

as semi-optimal rockburst-energy characteristics or the conditional probability of rockburst if the tremor of energy $E>E 1$ has occurred, no matter what the other geological or mining conditions are.

An analogous table and procedure was applied to the observed probabilities of rockburst, expressed as the function of exploitation depth, resulting in semi-optimal rockburst-depth characteristics (for a few coal-mines of KHW S.A. Holding):

$$
P(T \mid H)=\frac{1}{1+\exp [-0.0128(H-1128)]}
$$

The same method can be applied to any HSF from the MRG Instruction, resulting in semi-optimal local factorial characteristics, which - for any local value of $\theta_{i}{ }^{*}$ - become scalar and can be inserted into $(1.6 \mathrm{a}, \mathrm{b})$ to allow for semi-optimal hazard evaluation. When there is not enough data to calibrate the $\operatorname{HSF}(i)$ characteristics, the points $Q\left(i, \theta_{i}\right)$ from the MRG Instruction can be applied in the form:

$$
0 \leq P\left(T \mid Q\left(i, \theta_{i}\right)\right)=\frac{1}{1+\exp \left[-Q\left(i, \theta_{i}\right)\right]} \leq 1
$$

which is not optimal (and can be far from optimal) but can be interpreted as the roughly approximated probability of $P\left(T \mid \theta_{i}\right)$ and applied in formulas $(1.6 \mathrm{~b}, \mathrm{c})$. Next, to evaluate $Z^{T}$, it is necessary to estimate $Z^{S T}$.

\section{Seismic hazard estimation and $Z^{S T}$}

Assuming the well-known Pareto (or, in logarithmic form, the Gutenberg-Richter) law of energy-frequency distribution (Utsu 1999; Lasocki 1990) and uncorrelated, Poissonian 
tremors' sequence ${ }^{1}$ (Lasocki 1990; Kornowski, Kurzeja 2008) the expected value of the seismic hazard $\left(Z^{S}\right)_{\Delta t}^{12}$, or $\left(Z^{S}\right)_{\Delta t}^{1}$ if $E 2 \rightarrow \infty$, see $D 1$, can be estimated according to the formula (Lasocki 1990):

$$
\left(Z^{S}\right)_{\Delta t}^{1}=1-\exp \left[-\lambda \cdot \Delta t \cdot\left(E_{\bullet}\right)^{-B}\right]
$$

where $\left(Z^{S}\right)_{\Delta t}^{1}$ is the probability of a seismic event of energy $E>E 1, E_{\bullet}=E 1 / E_{-}$is the normalized energy, $B$ is the (so-called) G-R parameter, and the emission intensity, denoted $\lambda$, is the mean number of events $\left(E>E_{-}\right)$per time unit.

It should be noted that values of $(E 1, E 2)$ and $\Delta t$ are predetermined by the user (frequently with $E 2 \rightarrow \infty$ ), but values of $\lambda$ and $B$ are estimated from the information base (i.e. archive of local events $E>E_{-}$).

Inserting (3.1) and (2.2) into (1.5b) one obtains

$$
0 \leq\left(Z^{S T}\right)_{\Delta t}^{1}=\frac{1-\exp \left[-\lambda \cdot \Delta t \cdot\left(E_{\bullet}\right)^{-B}\right]}{1+\exp \left[-\alpha\left(\log E_{\bullet}-\beta_{\bullet}\right)\right]} \leq 1
$$

where $E_{\bullet}=E 1 / E_{-}, \beta_{o}=\beta-\log E_{-}$,with $\alpha=1.676, \beta=8.438$ for data shown in Tabela 1 . This is the estimator of the rockburst hazard in stationary MPP, abbreviated $Z^{S T}$ and called "the seismic rockburst hazard", see D2. It estimates the rockburst hazard (or its upper limit) excluding any local information possibly present in HSFs. As the values of $\lambda$ and $B$ are estimated from observations, the $Z^{S T}$ value is always uncertain and should be treated as the mean value of the random variable.

\section{Rockburst hazard estimation}

The rockburst hazard $\left(Z^{T}\right)_{\Delta t}^{1}$ estimator of IWMK - specifying the rockburst probability (i.e. $\left.P(T) \equiv Z^{T}\right)$ inside the predefined limits $[(E>E 1),(t, t+\Delta t)]$ assuming the MPP and the local scenario $\mathrm{SCN}^{2}$ - can be written as $(1.6 \mathrm{a}, \mathrm{b})$ with $Z^{S T}$ specified in (3.2):

$$
0 \leq\left(Z^{T}\right)_{\Delta t}^{1}=\left\{F\left(\theta_{1}\right) \cdot F\left(\theta_{2}\right) \cdot \ldots \cdot F\left(\theta_{M}\right)\right\} \cdot \frac{1-\exp \left[-\lambda \cdot \Delta t \cdot\left(E_{\bullet}\right)^{-B}\right]}{1+\exp \left[-\alpha_{E}\left(\log E_{\bullet}-\beta_{\bullet}\right)\right]} \leq 1
$$

1 These assumptions constitute the Pareto - Poissonian Model (MPP) of events sequences

2 Scenario SCN is quantitatively defined if locally active HSFs are known and their parameters have been estimated. In the worst case (of lacking the data), equation (2.3b) can be applied but then the estimation result is not optimal. 
As has been argued, all the elements of this estimator can be (approximately) evaluated and the resulting hazard estimate, $Z^{T}$, can be interpreted as the (uncertain) estimate of the mean probability of rockburst, given [(E>E1), $(t, t+\Delta t), \mathrm{SCN}]$. It should be stressed that the distribution of $Z^{T}$ interpreted as a random variable, is neither normal nor symmetric, and its standard uncertainty (defined as the distance between the order 0.84 and 0.5 ) strongly depends both on the quality and on the size of the data archives, but this subject is beyond the scope of this paper.

To illustrate the simplicity of applying formula (4.1) to real rockburst hazard estimation, the following example is demonstrated:

- in a coal mine of KHW S.A., $\left(Z^{S}\right)_{\Delta t}^{1}$ is to be estimated for $\Delta t=2$ days and energy $E 1=5 \cdot 10^{5} \mathrm{~J}$, for scenario $\operatorname{SCN}\left\{\theta_{1}=600 \mathrm{~m} ; \theta_{2}\right.$ : in the seam, rockburst has been previously observed, so $Q\left(2, \theta_{2}\right)=0$ according to MRG; seam thickness $\theta_{8}=3,1 \mathrm{~m}$, so that $Q\left(8, \theta_{8}\right)=1$; no other HSF active $\}$. From the database it has been estimated that $E_{-}=1 \cdot 10^{4} \mathrm{~J}$ ( so $E_{\bullet}=E 1 / E_{-}=50, \beta_{\mathrm{o}}=8.438=\log E_{\bullet}=6.739$ ), $B=0.85$ and $\lambda=2.2$ (events $E>E_{-}$daily). This is an actual but simplified example.

Estimation:

With equation $(2.3 \mathrm{a}, \mathrm{b})$ it can be calculated, for the given $\mathrm{SCN}$, that

$$
\begin{aligned}
& P\left(T \mid \theta_{1}{ }^{*}\right)=\{1+\exp [-0.0128(H-1128)]\}^{-1}=0.00116 \\
& P\left(T \mid Q\left(2, \theta_{2}\right)\right)=[1+\exp (0)]^{-1}=0.5 \\
& P\left(T \mid Q\left(8, \theta_{8}\right)\right)=[1+\exp (-1)]^{-1}=0.73106
\end{aligned}
$$

and with (3.2), for $\Delta t=2, E 1 \bullet=50, B=0.85$ ) the calculation is:

$$
\left(Z^{S T}\right)_{\Delta t}^{1}=\frac{1-\exp \left[-2.2 \cdot 2 \cdot E_{\bullet}^{*-0.85}\right]}{1+\exp \left[-1.676\left(\log E_{\bullet}^{*}-6.739\right)\right]}=0.00003138
$$

and finally

$$
\left(Z^{T}\right)_{\Delta t, S C N}^{1}=0.00116 \cdot 0.5 \cdot 0.73106 \cdot 0.00003138=1.33056 \cdot 10^{-8}
$$

This value is the (uncertain) estimate of the mean value of $Z^{T}$ under the specified conditions.

Note that whatever is the (realistic) division of "hazard space" (i.e. $0-1$ segment of real numbers) into states $(a, b, c, d)$, this is a very small probability of rockburst (during the nearest 2 days). 


\section{Conclusion}

1. The approximate rockburst hazard estimator/predictor called the "IWMK estimator" based on the existing Comprehensive Method of Rockburst Hazard Evaluation, CMRHE, commonly applied in the Polish mining industry - has been formulated in the form of equation (4.1). Its components are easy to calculate (given a sufficient database) and have simple physical interpretation.

2. Factors of $Z^{M R G}$ can be interpreted as factorial characteristics of so-called Hazard Shaping Factors and expressed in parametric forms with parameters optimized to fit the observations. In this way the whole estimator (4.1) can be approximately but easily optimized, improving the possibility of better rockburst probability prediction.

3. All the elements of estimator (4.1) can be interpreted as probabilities, so the rules of operation are defined by probability theory. From a theoretical point of view, this is the most important result of this work.

4. There is a simple connection between the CMRHE and the authors' IWMK.

5. The IWMK can be generalized, taking into account other sources of information by simply inserting other Hazard Shaping Factors or deleting those which are unneeded.

6. The quality of results (in practice) depends not only on the size and quality of data archives, but also on the physical correctness of the CMRHE itself, which is the basis of the IWMK.

\section{REFERENCES}

Barański et al. 2007 - Barański A., Drzewiecki J., Kabiesz J., Konopko W., Kornowski J., Krzyżowski A., Mutke G., 2007 - Zasady stosowania metody kompleksowej i metod szczegółowych oceny stanu zagrożenia tąpaniami w kopalniach węgla kamiennego. Seria Instrukcje nr 20. GIG, Katowice.

De Gr o ot M.H., 1970 - Optimal statistical decisions. McGraw-Hill.

D u bińs k i J., 1994 - Związki przyczynowe wstrząsów i tąpań. Przegląd Górniczy, vol. 2, Katowice, 6-10.

Falanesca et al. 2010 - F a l a n e s c a M., B o ri o L., P i c c h i o A., P e i l a D., 2010 - QuaRRi: a new methodology for rock-fall risk analysis and management in quarry exploitation. Gospodarka Surowcami Mineralnymi, vol. 26(4), 149-161.

Kornowski J., 2010 - Formalna metoda łącznej oceny zagrożenia tąpnięciem na podstawie informacji geofizycznej i Metody Rozeznania Górniczego. Górnictwo i Środowisko, Nr 2/2010, GIG, Katowice, 47-62.

Kornowski J., Kurzeja J., 2008 - Krótkookresowa prognoza zagrożenia sejsmicznego w górnictwie. GIG, Katowice.

Kornowski J., Kurzeja J., 2012 - Prediction of Rockburst Probability Given Seismic Energy and Factors Defined by the Expert Method of Hazard Evaluation (MRG). Acta Geophysica, vol. 60, no. 2, $472-486$.

La s o cki S., 1990 - Prediction of strong mining tremors, Z.N. AGH Geofizyka Stosowana, 7, 1-110 (in Polish with English abstract).

Marcak H., 2009 - Inverse problems in modeling mining shocks. Gospodarka Surowcami Mineralnymi Vol. 25(3), 217-225. 
Tarant o la A., 1987 - Inverse problem theory. Elsevier, Amsterdam.

Utsu T., 1999 - Representation and Analysis of the Earthquake Size Distribution: A Historical Review and Some New Approaches. Pure Appl. Geophys., vol. 158, 1655-1675.

\title{
PODSTAWOWE ZALOŻENIA ILOŚCIOWEJ WERSJI KOMPLEKSOWEJ METODY OCENY STANU ZAGROŻENIA TĄPANIAMI
}

\author{
Słowa kluczowe
}

Tąpania, zagrożenie tạpaniami, sejsmologia górnicza

\section{Streszczenie}

W artykule opisano podstawy i wyniki stosowania nowej, ilościowej wersji znanej w polskim górnictwie Kompleksowej Metody Oceny Stanu Zagrożenia Tapaniami (ang.: CMRHE). W skład Metody Kompleksowej (MK) wchodzą cztery tzw. „metody szczegółowe”: sejsmologii górniczej, sejsmoakustyki, wierceń małośrednicowych i „ekspercka” metoda rozeznania górniczego. Mimo swej popularności, MK nie jest dobrze zdefiniowana w sensie matematycznym: ani sama MK ani żadna z metod szczegółowych nie definiują ilościowo przedmiotu swego zainteresowania, tzn. zagrożenia tąpaniami, wskutek czego usiłują one ocenić lub prognozować niezdefiniowaną wielkość. Nie ma też pewności, że każda z metod bada tę samą wielkość fizyczną i nie jest oczywiste w jaki sposób poprawnie łączyć wyniki metod szczegółowych by otrzymać poszukiwane wynikowe zagrożenie. Opisana tu wersja ilościowa MK, od samego początku definiuje zagrożenie tąnięciem jak również wszystkie jego składniki jako prawdopodobieństwa, na których wszelkie przekształcenia mogą być dokonywane zgodnie z zasadami rachunku prawdopodobieństwa. W artykule zademonstrowano, że wszystkie informacje o czynnikach kształtujących zagrożenie, które wykorzystywane są w oryginalnej Metodzie Kompleksowej, mogą być przedstawione w formie rozkładów prawdopodobieństwa - zawsze zależnych od właściwej zmiennej objaśniającej a dla konkretnej, lokalnej wartości tej zmiennej, każdy rozkład daje skalarną wartość prawdopodobieństwa. Iloczyn tych rozkładów prawdopodobieństwa jest estymatorem zagrożenia tąpnięciem i jest oparty na dokładnie tej samej informacji co oryginalna ocena z MK. Można zauważyć, że logarytm iloczynu prawdopodobieństw daje sumę składników, analogiczną lecz nie identyczną względem sumy „punktów” w oryginalnej MK, co podkreśla bezpośredni związek opisanej tu ilościowej wersji z oryginalną MK. W końcowej części artykułu przedstawiono przykład oceny zagrożenia tąpnięciem, ilustrując prostotę metody.

THE BASIC ASSUMPTIONS OF THE QUANTITATIVE VERSION OF THE COMPREHENSIVE METHOD OF ROCKBURST HAZARD EVALUATION

$$
\text { Key words }
$$

Rockburst, rockburst hazard, mining seismology

\section{Abstract}

This article describes the process and results of applying a new, quantitative version of what is, in the Polish mining industry, a well-known, so-called Comprehensive Method of Rockburst Hazard Evaluation (CMRHE) The CMRHE is composed of four "particular methods" (i.e. mining seismology, seismoacoustics, drilling, and the partly subjective "expert method of hazard evaluation"). Despite its popularity, CMRHE is not well defined in the mathematical sense. The subject, i.e. the rockburst hazard, is not quantitatively (or otherwise) well defined within the CMRHE Instructions or the four particular methods. In fact, the CMRHE tries to predict an undefined 
subject, and there is no guarantee that the particular methods attempt to identify the same (undefined) hazard. It is not clear how the four particular results should be combined to arrive at the final hazard prediction.

The quantitative version, described here, starts by defining the hazard and all of its components as probabilities. These can then be combined according to probability rules. This analysis demonstrated that all the relevant pieces of (presumably independent) information - exactly the same as applied by CMRHE - can be expressed as probability distributions, each one dependent on its explanatory variable and each one assuming a scalar value under any concrete local conditions. Using the quantitative version of CMRHE, the product of these distributions bases the formal estimator of rockburst hazard on exactly the same information as the original CMRHE. The fact that the logarithm of this product is the sum of "points" stresses the simple connection between the original CMRHE and its quantitative version.

An example using actual (albeit compressed) data illustrates the simplicity of this application. 